\title{
Potential of Potassium Supply in Locally Available Soil Amendments for Use in Coconut Plantations
}

\author{
H.M.I.K. Herath
}

\begin{abstract}
Potassium $(\mathrm{K})$ is an essential macro nutrient which plays a vital role in crop growth and development. Most of the tropical soils are having low level of potassium and crops grown on these soils are heavily dependent on mineral fertilizers for the supply of potassium. Organic growers are in need of locally available natural source of potassium as they have restrictions on use of synthetic fertilizers. A pot experiment was conducted on sandy regosol to investigate the potassium supplying ability to soil from locally available potassium containing materials. The treatments were, T1-Control (no amendments added), ground mica (T2), feldspar (T3), coconut husk ash (T4), Tithonia diversifolia (T5), muriate of potash (T6) for comparison. Materials were analyzed for nutrient content and applied at the rate equivalent to recommended $K$ level for adult coconut palm. Soil samples were extracted from each pot at one-month interval for analysis. Results show that higher exchangeable $K$ level has been maintained (1.5-3.8 meq/100g soil) by $T 4$ during the experimental period while $\mathrm{T} 1, \mathrm{~T} 2$, T3 and T6 had significantly lower $(<0.05$ meq/100g soil) exchangeable $K$. In addition, T4 has increased soil $\mathrm{pH}$ towards neutral level and higher exchangeable $\mathrm{Mg}$ and available $P$. Treatments $T 5$ and $T 4$ also showed significantly higher exchangeable $\mathrm{K}$ than T1, T2 and T3. The results indicate that coconut husk ash and Tithonia diversifolia have a greater potential to be used as a source of potassium with additional advantage of enhanced availability of
\end{abstract}

Soils and Plant Nutrition Division, Coconut Research Institute, Lunuwila. indikaherath@hotmail.com other nutrients.

Keywords: Organic cultivation, Soil nutrient availability, Soil potassium

\section{INTRODUCTION}

Potassium is a major plant nutrient taken up by plants through roots from soil. As potassium is associated with many functions in plants like transportation of nutrients, carbohydrates and water, if potassium is not adequately supplied, plant growth get retarded (Oosterhuis et. al, 2013; Wakeel, 2013). A larger area of agricultural lands around the world is deficient in potassium (Rengel and Damon, 2008). The supply of $\mathrm{K}$ from the soil is often insufficient to meet the demand in many agricultural systems (White, 2013). Therefore, most of the cropping systems on highly weathered soils, especially in tropics, are heavily depend on mineral fertilizers for supply of potassium. Such soils commonly occur in developing countries (Manning, 2010).

Furthermore, in organic cultivation systems, application of synthetic fertilizers is not allowed. Animal manure and compost made from plant residues and animal waste consist of considerable amounts of nitrogen and phosphorus, however low amount of potassium. Therefore, growers are in need 
of alternative sources of potassium for these systems. This is common among coconut (Cocos nusifera) growers as coconut is a high potassium demanding crop. Nuts and husk of coconut contain higher amount of potassium than other parts and in general, harvested nuts are taken away from the field for processing or consumption. Therefore, there is a continuous flow of potassium moving out from the plantation making coconut growing soils low in potassium. Moreover, the present high cost of conventional potassium fertilizers further justifies investigation of alternative potassium sources.

Mica and Feldspar are considered as a naturally occurring mineral sources of $\mathrm{K}$. The lower solubility of $\mathrm{K}$ from these materials limits their use (Cooray et.al., 1992). Some plant materials such as Tithonia diversifolia are considered to be rich in K. Tithonia diversifolia is a species of flowering plant in the Asteraceae family that is commonly known as wild sunflower, tree marigold or Mexican sunflower. In some large-scale coconut plantations growers tend to plant them. Tithonia diversifolia has shown great potential in raising the soil fertility in soils depleted in nutrients (Jama et al., 2000). This plant grows wildly in some areas of Sri Lanka and considers as a weed.

Coconut husk is another source of potassium and it is recommended to apply the mature husk back into coconut fields for moisture conservation and as a nutrient source. However, most of the growers are reluctant to apply them to the field due to various reasons.

Therefore, the objective of this study was to evaluate potassium supplying potential of locally available soil amendments to be used in coconut plantations. Commonly use $\mathrm{K}$ fertilizer source, Muriate of Potash (MOP) was used as a treatment for comparison purpose. This study further evaluates the changes in soil $\mathrm{pH}$ and the availability of other nutrients as a result of applying the same soil amendments.

\section{MATERIALS AND METHODS}

\section{Experimental Location and Soil Type}

This research study was conducted as a pot experiment under a greenhouse condition using a common coconut growing Sandy Regosol (USDA: Aquic Quartzipsamments, uncoated sandy, non calcarious; FAO: Orthridystric Regosols). Soil samples were collected from $5-20 \mathrm{~cm}$ depth of a matured coconut plantation in the Intermediate Zone of Sri Lanka. Soils were air-dried for one week and passed through $5 \mathrm{~mm}$ mesh to remove any stones, rock pieces and plant debris. Then the pots $(20 \mathrm{~cm}$ diameter and $35 \mathrm{~cm}$ height) were filled with $5 \mathrm{~kg}$ of soil and treatments were applied.

\section{Treatments and Experimental Design}

Locally available sources known to be rich in potassium were used as treatments in this experiment (Table1). Muriate of potash 
(MOP), the common potassium supplying fertilizer used in coconut cultivation in Sri Lanka was also used as treatment for comparison purposes.

Table 1: Treatments of the experiment, potassium contents and the rates of application

\begin{tabular}{|c|c|c|c|}
\hline Treatment & $\begin{array}{l}\text { Amendment } \\
\text { added }\end{array}$ & $\begin{array}{l}\text { Amount } \\
\text { of } \\
\mathrm{K} \\
\left(\% \mathrm{~K}_{2} \mathrm{O}\right)\end{array}$ & $\begin{array}{c}\text { Amount } \\
\text { applied } \\
\text { per pot } \\
\text { (g) }\end{array}$ \\
\hline $\mathrm{T} 1$ & $\begin{array}{l}\text { No } \\
\text { amendment } \\
\text { added }\end{array}$ & & 0 \\
\hline $\mathrm{T} 2$ & Mica powder & 8.26 & 29 \\
\hline $\mathrm{T} 3$ & $\begin{array}{l}\text { Feldspar } \\
\text { (ground) }\end{array}$ & 8.95 & 26 \\
\hline $\mathrm{T} 4$ & $\begin{array}{l}\text { Coconut husk } \\
\text { ash }\end{array}$ & 17.91 & 13 \\
\hline T5 & $\begin{array}{ll}\text { Tithonia } & \text { (air } \\
\text { dried } & \text { and } \\
\text { ground) } & \end{array}$ & 3.08 & 78 \\
\hline T6 & $\begin{array}{l}\text { Muriate of } \\
\text { Potash }\end{array}$ & 60 & 4 \\
\hline
\end{tabular}

Potassium application rate was decided based on $\mathrm{K}$ levels of the treatment materials and the $\mathrm{K}$ application rate recommended by Coconut Research Institute of Sri Lanka for adult coconut in their manure circle $\left(48 \mathrm{~g} \mathrm{~K}_{2} \mathrm{O} / 100 \mathrm{~kg}\right.$ of soil in the manure circle). The experimental was designed as a Completely Randomized Design with three replicates per each treatment.

\section{Collection of Treatment Material and Application}

Samples of phlogopite mica powder [K $\left.(\mathrm{Mg})_{3} \mathrm{AlSi}_{3} \mathrm{O}_{10}(\mathrm{OH}, \mathrm{F})_{2}\right]$ were collected from a mica processing centre, Matale, Sri Lanka and $\mathrm{K}$-feldspar $\left[\mathrm{K}(\mathrm{Al}, \mathrm{Si})_{3} \mathrm{O}_{8}\right]$ in ground form was collected from a feldspar deposit at Kaikawala, Sri Lanka. Coconut husk ash was produced by burning dried mature coconut husk in open fire allowing full burn in an earth pit. The coconut husks were collected from Bandirippuwa Estate, Lunuwila in the Intermediate Zone of Sri Lanka. Tithonia diversifolia, commonly known in Sri Lanka as wild sunflower (immature to semi-hard woody branches with leaves) was collected from Madampe area the Intermediate Zone of Sri Lanka. These branches and leaves were allowed to dry under atmospheric conditions for one week and applied in ground form. Muriate of Potash (MOP) fertilizer was obtained from retail market. After application, the treatment materials were well incorporated to soil within $30 \mathrm{~cm}$ depth using a spade. The pots were watered once in every two days with equal amount of water. It was assured not to apply water beyond saturation as to avoid leaching losses of nutrients. Soil samples were extracted at $15 \mathrm{~cm}$ depth from the surface of each pot in one-month intervals. The experiment was continued for 5 months.

\section{Analysis of Treatment Materials and Soil Samples}

Treatment materials were analyzed for their potassium content. The soil used for filling up pots were initially analyzed for the chemical properties. The collected soil samples were analyzed every month for exchangeable potassium using $\mathrm{NH}_{4} \mathrm{OAc}$ extraction method. For other chemical 
parameters soil samples were analyzed at $1^{\text {st }}, 3^{\text {rd }}$ and $5^{\text {th }}$ month after treatment application. The other chemical properties tested were soil $\mathrm{pH}$ (1:2.5 Soil: water) using glass electrode, exchangeable magnesium ( $\mathrm{NH}_{4} \mathrm{OAc}$ extraction) and available phosphorus using Olsen method (Olsen et al., 1954).

\section{RESULTS AND DISCUSSION}

Chemical properties of soil before application of treatments are given in the Table 2. Soil has an acidic soil $\mathrm{pH}$ and very low level of exchangeable potassium and magnesium. The soil has available phosphorus content less than $10 \mathrm{ppm}$ and it is considered as a low phosphorus level.

Table 2: Initial properties of soil used in the experiment

\begin{tabular}{lc}
\hline \multicolumn{1}{c}{ Parameter } & Value (Mean \pm SD) \\
\hline Soil pH & $4.33 \pm 0.08$ \\
& $(1: 2.5$ soil: water $)$ \\
Exchangeable K & $0.04 \pm 0.003$ meq $/ 100 \mathrm{~g}$ \\
Available $\mathrm{P}$ & $6.29 \pm 0.07 \mathrm{ppm}$ \\
Exchangeable $\mathrm{Mg}$ & $0.036 \pm 0.007 \mathrm{meq} / 100 \mathrm{~g}$ \\
\hline
\end{tabular}

\section{Soil pH}

The soil $\mathrm{pH}$ was significantly increased in the coconut husk ash added treatment and also in the wild sunflower added treatments. However, there were no significant difference in soil $\mathrm{pH}$ of control, mica, feldspar and MOP added treatments throughout the experimental period (Table
3). The treatment with added coconut husk ash has been able to bring its soil $\mathrm{pH}$ to a neutral level and maintained in a neutral range (7.06-6.91) throughout the experimental period. This would be useful to make other major nutrients available as most macro nutrients increase their availability in the neutral $\mathrm{pH}$ levels.

Table 3: Soil $\mathrm{pH}$ after application of treatments

\begin{tabular}{lccc}
\hline Treatment & \multicolumn{3}{c}{$\mathrm{pH}$ value (1: 2.5 soil: water) } \\
\cline { 2 - 4 } & 1 month & 3 months & 5 months \\
\hline Control & $4.32^{\mathrm{c}}$ & $4.30^{\mathrm{c}}$ & $4.38^{\mathrm{c}}$ \\
Mica & $4.31^{\mathrm{c}}$ & $4.38^{\mathrm{c}}$ & $4.40^{\mathrm{c}}$ \\
Feldspar & $4.38^{\mathrm{c}}$ & $4.33^{\mathrm{c}}$ & $4.42^{\mathrm{c}}$ \\
Coconut & $7.06^{\mathrm{a}}$ & $6.96^{\mathrm{a}}$ & $6.91^{\mathrm{a}}$ \\
husk ash & & & \\
Tithonia & $5.89^{\mathrm{b}}$ & $5.67^{\mathrm{b}}$ & $5.61^{\mathrm{b}}$ \\
Muriate of & $4.33^{\mathrm{c}}$ & $4.40^{\mathrm{c}}$ & $4.41^{\mathrm{c}}$ \\
Potash & & & \\
\hline
\end{tabular}

Note: Mean values indicated by same letter along the columns are not significantly different at $\alpha=0.01$

\section{Soil Exchangeable Potassium}

Soil exchangeable potassium content was significantly higher in coconut husk ash treatment compared to all other treatments in all samplings except the sampling at $2^{\text {nd }}$ month after treatment application (MATA). The highest exchangeable $\mathrm{K}$ content of 3.8 meq/100g of soil was given by coconut husk ash treatment at 4 MATA (Figure 1). These results show that the coconut husk ash has a great potential of supplying $\mathrm{K}$.

The reason for having higher $\mathrm{K}$ content than MOP would be the increase of soil $\mathrm{pH}$ towards the neutral level. 


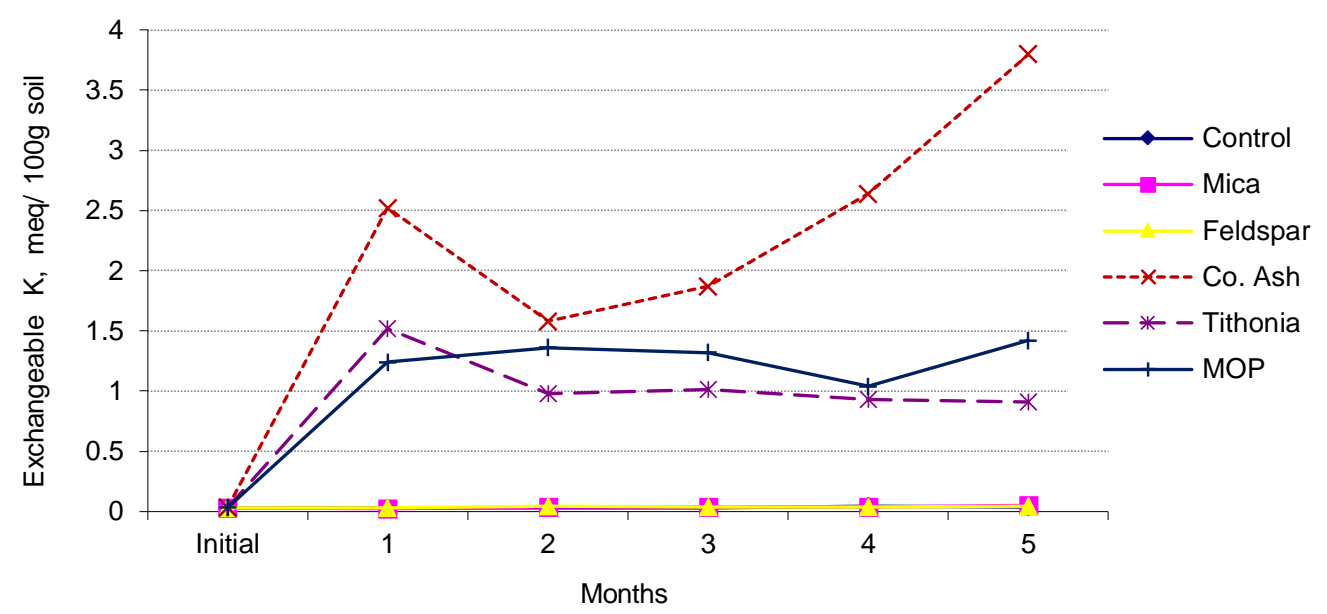

Figure 1: Variation in soil exchangeable potassium of different treatments over the experimental period

According to the $\mathrm{K}$ content of coconut husk ash, annual $\mathrm{K}$ need of adult coconut palm can be met by adding $5.36 \mathrm{~kg}$ of husk ash. This will also have the advantage of increasing soil $\mathrm{pH}$ in acidic soils.

The lowest $\mathrm{K}$ content was observed in the control, mica and feldspar treatments recording less than 0.05 meq $/ 100 \mathrm{~g}$ exchangeable $\mathrm{K}$ levels in soil throughout the experimental period. This fact indicates that the release of $\mathrm{K}$ from mica and feldspar has not been happened during the experimental period. Cooray et al. (1992) have also observed low availability of $\mathrm{K}$ from application mica. The wild sunflower treatment (T5) showed significantly higher exchangeable $\mathrm{K}$ content than control, mica and feldspar treatments but significantly lower than T4. There was no significant difference in soil exchangeable $\mathrm{K}$ between T6 and T5 at 1 and 4 MATA. This fact Tithonia diversifolia to be used as a source of potassium.

When the amount of T.diversifolia needed to supply annual $\mathrm{K}$ requirement is calculated, it rises to a value of $31.16 \mathrm{~kg}$ for one adult cocopalm which may seem to be a practically difficult amount for application. Being an organic manure, application of $T$. diversifolia has an added advantage of enhancing soil organic matter which leads to multiple benefits with respect to soil fertility.

\section{Soil Exchangeable Magnesium}

A significantly higher exchangeable $\mathrm{Mg}$ contents were observed in coconut husk ash treatment and $T$. diversifolia treatment compared to all other treatments throughout the experimental period. This can be considered as an advantage of $\mathrm{T} 2$ and $\mathrm{T} 3$ to have a higher $\mathrm{K}$ and $\mathrm{Mg}$ content. 
Table 4: Changes in soil exchangeable Magnesium after application of treatments

\begin{tabular}{lccc}
\hline Treatment & \multicolumn{3}{c}{$\begin{array}{c}\text { Soil exchangeable Mg } \\
(\mathrm{meq} / 100 \mathrm{~g} \text { of soil) }\end{array}$} \\
\cline { 2 - 4 } & 1 month & 3 months & 5 months \\
\hline Control & $0.04^{\mathrm{b}}$ & $0.04^{\mathrm{b}}$ & $0.05^{\mathrm{b}}$ \\
Mica & $0.07^{\mathrm{b}}$ & $0.07^{\mathrm{b}}$ & $0.08^{\mathrm{b}}$ \\
Feldspar & $0.04^{\mathrm{b}}$ & $0.05^{\mathrm{b}}$ & $0.04^{\mathrm{b}}$ \\
$\begin{array}{l}\text { Coconut } \\
\text { husk ash }\end{array}$ & $0.34^{\mathrm{a}}$ & $0.42^{\mathrm{a}}$ & $0.44^{\mathrm{a}}$ \\
Tithonia & $0.33^{\mathrm{a}}$ & $0.36^{\mathrm{a}}$ & $0.35^{\mathrm{a}}$ \\
$\begin{array}{l}\text { Muriate of } \\
\text { Potash }\end{array}$ & $0.05^{\mathrm{b}}$ & $0.04^{\mathrm{b}}$ & $0.05^{\mathrm{b}}$ \\
\hline
\end{tabular}

Note: Mean values indicated by same letter along the columns are not significantly different at $\alpha=0.01$

Even though mica has $\mathrm{Mg}$ in its chemical formula, release of $\mathrm{Mg}$ to exchangeable pool has not been happened during the experimental period (Table 4).

\section{Soil Available Phosphorus}

It was observed that the available phosphorus content significantly increased in T4, the coconut husk ash treatment compared to all other treatments. The T5 treatment also showed increment in available $\mathrm{P}$ than $\mathrm{T} 1, \mathrm{~T} 2, \mathrm{~T} 3$ and T6 but lower than T4. This could be mainly due to the increase of $\mathrm{pH}$ to a neutral level. The phosphorus availability in soil is generally limited both in acidic and alkaline $\mathrm{pH}$ conditions (Table 5).
Table 5: Changes in soil available Phosphorus after application of treatments

\begin{tabular}{|c|c|c|c|}
\hline \multirow[t]{2}{*}{ Treatment } & \multicolumn{3}{|c|}{$\begin{array}{c}\text { Soil Available P } \\
\text { (ppm) }\end{array}$} \\
\hline & 1 month & 3 months & 5 months \\
\hline Control & $6.32^{c}$ & $6.30^{c}$ & $7.38^{c}$ \\
\hline Mica & $6.21^{\mathrm{c}}$ & $7.38^{\mathrm{c}}$ & $7.40^{\mathrm{c}}$ \\
\hline Feldspar & $7.38^{c}$ & $6.33^{\mathrm{c}}$ & $7.42^{c}$ \\
\hline $\begin{array}{l}\text { Coconut husk } \\
\text { ash }\end{array}$ & $12.06^{\mathrm{a}}$ & $11.96^{\mathrm{a}}$ & $11.91^{\mathrm{a}}$ \\
\hline Tithonia & $8.89^{\mathrm{b}}$ & $9.67^{b}$ & $9.61^{\mathrm{b}}$ \\
\hline $\begin{array}{l}\text { Muriate of } \\
\text { Potash }\end{array}$ & $4.33^{\mathrm{c}}$ & $4.40^{\mathrm{c}}$ & $4.41^{\mathrm{c}}$ \\
\hline
\end{tabular}

Note: Mean values indicated by same letter along columns are not significantly different at $\alpha=0.01$

\section{CONCLUSION}

Coconut husk ash has a greater potential of supplying potassium with providing additional advantages of increasing the availability of $\mathrm{Mg}$ and $\mathrm{P}$, and also by enhancing soil $\mathrm{pH}$ to a neutral $\mathrm{pH}$ range. The coconut husk ash needed for complete replacement of $\mathrm{K}$ requirement of an adult coconut palm is calculated as $5.36 \mathrm{~kg}$. Coconut husks are in demand for various other industries which may limit the use of them for this purpose.

Next to Coconut husk ash, Tithonia diversifolia has a potential to use as an amendment rich in $\mathrm{K}$ with its enhanced availability of providing phosphorus and exchangeable Mg. The needed amount of Tithonia diversifolia to meet annual $\mathrm{K}$ requirement for an adult coconut palm was calculated to be $31.16 \mathrm{~kg}$. As Tithonia 
diversifolia has proven ability to thrive in relatively low fertile soils, there is a potential to use it in coconut plantations by cultivating them in underutilized land pockets with proper land use planning.

\section{ACKNOWLEDGEMENT}

The author wishes to acknowledge the Head and the staff of the Soils and Plant Nutrition Division of the Coconut Research Institute of Sri Lanka for the support given throughout the experimental period.

\section{REFERENCES}

Cooray, P. I., Weerassoriya, T. J. and Deturck, P. (1992) Effect of acidulated pigmatatic mica on growth and yield of rice and soil solution $\mathrm{K}, \mathrm{Mg}$, Ca. Journal of the Geological Society of Sri Lanka, 4: 69-75.

Jama, B., Palm, C. A., Buresh, R. J., Niang, A., Gachengo, C., Nziguheba, G. (2000). Tithonia diversifolia as a green manure for soil fertility improvement in western Kenya: A review. Agroforestry Systems. 49: 202

Manning, D. A. C (2010). Mineral sources of potassium for plant nutrition. A review. Agronomy for Sustainable Development, 30 (2010): 281-294

Olsen, S.R., C.V. Cole, F.S. Watanabe, and L.A. Dean. (1954). Estimation of available phosphorus in soils by extraction with sodium bicarbonate. Circular (United States. Dept. of Agriculture, 939.
Oosterhuis, Derrick M., Loka, Dimitra A., and Raper, Tyson B. (2013). Potassium and stress alleviation: Physiological functions and management of cotton. Journal of Plant Nutrition and Soil Science, 176 (3): 331-343.

Doi: 10.1002/jpln.201200414

Rengel, Z., and Damon, P. M. (2008). Crops and genotypes differ in efficiency of potassium uptake and use. Journal of Plant Physiology.

Doi: 10.1111/j.13993054.2008.0107 9.X

Wakeel, A. (2013). Potassium-sodium interactions in soil and plant under saline-sodic conditions. Journal of Plant Nutrition and Soil Science, 176 (3): 344-354.

Doi: $10.1002 /$ jpln.201200417

White, P. J. (2013). Improving potassium acquisition and utilisation by crop plants. Journal of Plant Nutrition and Soil Science, 176 (3): 305-316. Doi: 10.1002/jpln.20120012 